\title{
Estimating Denitrification Rates in the East/Japan Sea Using Extended Optimum Multi-Parameter Analysis
}

\author{
Il-Nam Kim* \\ Department of Marine Science, Incheon National University, Incheon, South Korea
}

Received 6 April 2014, revised 10 September 2014, accepted 24 September 2014

\begin{abstract}
Denitrification rates in the East/Japan Sea (EJS) were examined with extended Optimum Multi-Parameter (eOMP) analysis. The potential denitrification locations expected from the eOMP analysis occurred only in the Ulleung Basin (UB) and near the Tatar Strait (TtS) of the Eastern Japan Basin (EJB). Estimated denitrification rates were $\sim 0.3-3$ and $\sim 4-11 \mu \mathrm{mol} \mathrm{N} \mathrm{m}^{-2} \mathrm{~d}^{-1}$ in the UB and in the EJB, respectively. These rates agree with previous published results. The EJS's rates were lower than reported for other marginal seas. However, considering the rapid EJS response to climate change, we predict that denitrification may be enhanced in the near future.
\end{abstract}

Key words: Extended Optimum Multi-Parameter analysis, East/Japan Sea, Denitrification

Citation: Kim, I. N., 2015: Estimating denitrification rates in the East/Japan Sea using extended Optimum Multi-Parameter analysis. Terr. Atmos. Ocean. Sci., 26, 145-152, doi: 10.3319/TAO.2014.09.24.01(Oc)

\section{INTRODUCTION}

The East/Japan Sea (EJS) is a semi-enclosed marginal sea in the northwestern North Pacific Ocean that exhibits many dynamic characteristics, e.g., deep-water formation, subpolar front, eddy, and gyre circulation (Talley et al. 2006). The EJS is often referred to as a "Miniature Ocean" (Kim et al. 2001). The EJS is also well known as an optimal location to study modern climate change due to the short hundred year time scale residence time (Kim and Kim 1996; Kim et al. 2001).

Denitrification $\left(\mathrm{NO}_{3}{ }^{-} \rightarrow \mathrm{NO}_{2}{ }^{-} \rightarrow \mathrm{N}_{2} \mathrm{O} / \mathrm{N}_{2}\right)$, which occurs in low oxygen environments, is the most significant mechanism responsible for nitrogen loss in the ocean environment (Brandes et al. 2007). Denitrification reduces the bioavailable nutrient N/P ratio because nitrate serves as an oxidant instead of $\mathrm{O}_{2}$ (Anderson and Sarmiento 1994). Denitrification has not been considered a significant process in the EJS nitrogen cycle because of high oxygen concentrations, which would not be conducive to conventional denitrification in this region. The EJS uniquely shows that dissolved oxygen concentrations are greater than $220 \mu \mathrm{mol} \mathrm{kg}{ }^{-1}$ at $1000 \mathrm{~m}$ depth in the North Pacific Ocean (see Fig. 1 of Talley et al. 2006).

\footnotetext{
* Corresponding author

E-mail:ilnamkim@inu.ac.kr
}

A number of recent studies have indicated that radical changes in the EJS are induced by climate change. Examples of these trends include: increases in air and sea temperatures (Gamo 1999; Min and Kim 2006), deepening of the oxygen minimum layer (Kim and Kim 1996; Chen et al. 1999; Kim et al. 2001; Kang et al. 2004, Kim et al. 2004), a change in the deep water formation mode (Gamo et al. 2001; Kang et al. 2003; Chae et al. 2005), and a prediction that anoxia may occur during the next century (Chen et al. 1999; Kang et al. 2004). Both indirect and direct evidence suggest the possibility for denitrification in the EJS (Talley et al. 2001; Yanagi 2002; Lee et al. 2007; Tishchenko et al. 2007; Jeong et al. 2009).

Several lines of evidence indicating denitrification signals on the continental slopes of the Ulleung Basin (UB) and the Eastern Japan Basin (EJB) were recently suggested by intensive nutrient profile analysis. Denitrification rates were estimated to be $\sim 3-33 \mu$ mol $\mathrm{N} \mathrm{m}^{-2} \mathrm{~d}^{-1}$ (Kim et al. 2012). Two hypotheses were presented to explain denitrification in the EJS: (1) the formation of mirco-reducing environments in the bottom waters, and (2) aerobic denitrification as a newly discovered process.

At present, verification of the respective hypotheses is difficult for the EJS, but examining denitrification rates with alternate approaches may provide mechanistic insights. 
The extended Optimum Multi-Parameter (eOMP) analysis estimated denitrification rates from coastal to marginal to open ocean scales (Hupe and Karstensen 2000; Kim and Min 2013; Kim et al. 2013). The main goals of this study are: (1) to investigate potential denitrification locations, and (2) to estimate denitrification rates using the eOMP analysis.

\section{DATA}

Two basin-wide hydrographic cruises were conducted in the summer of 1999 in the EJS via the Circulation Research of East Asian Marginal Seas II (CREAMS II) program (Fig. 1). More specific information on the cruise is available in Talley et al. (2004). The data used for this study were obtained from http://sam.ucsd.edu/. The parameters used for the eOMP analysis are latitude, longitude, pressure, potential temperature (PT), salinity (S), dissolved oxygen $(\mathrm{DO})$, nitrate $(\mathrm{N})$, phosphate $(\mathrm{P})$, silicate $(\mathrm{Si})$, total alkalinity (TALK), and dissolved inorganic carbon (DIC). The DIC values were calculated from total alkalinity and total $\mathrm{pH}$ through the CO2SYS program (Van Heuven et al. 2011). Only data below $300 \mathrm{~m}$ were analyzed to minimize seasonal variation influences. The EJS basin is divided into the Japan Basin (JB), the UB, and the Yamato Basin (YB). The JB is divided into the Western Japan Basin (WJB) and the EJB with a boundary along $135^{\circ} \mathrm{E}$, for more convenient analysis presentation (Fig. 1).

\section{THE EOMP ANALYSIS}

In general, the oceanic measurements are determined by physical mixing and biogeochemical processes together
(Anderson and Sarmiento 1994). The eOMP analysis provides one approach to consider physical mixing and biogeochemical processes together. Since then basic OMP analysis was developed (Tomczak and Large 1989), and improved and named the eOMP analysis (Poole and Tomczak 1999; Hupe and Karstensen 2000). The Si and TALK equations in the eOMP analysis were recently modified (Kim et al. 2013). The eOMP analysis matrix from is given as:

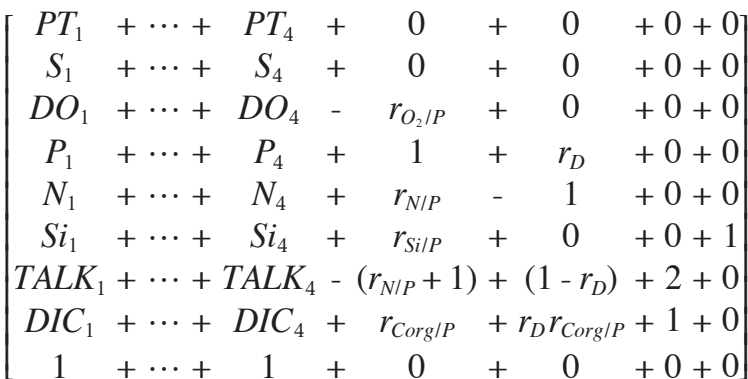

$$
\begin{aligned}
& \times\left[\begin{array}{c}
x_{1} \\
x_{2} \\
x_{3} \\
x_{4} \\
\Delta P_{\text {remi }} \\
\Delta N_{\text {deni }} \\
\Delta C_{\text {inorg }} \\
\Delta S i_{\text {inorg }}
\end{array}\right]-\left[\begin{array}{c}
P T_{o b s} \\
S_{o b s} \\
D O_{o b s} \\
P_{o b s} \\
N_{o b s} \\
S i_{o b s} \\
T A L K_{o b s} \\
D I C_{o b s} \\
1
\end{array}\right]=\left[\begin{array}{c}
R_{P T} \\
R_{S} \\
R_{D O} \\
R_{P} \\
R_{N} \\
R_{S i} \\
R_{T A L K} \\
R_{D I C} \\
R_{M C}
\end{array}\right]
\end{aligned}
$$

$A \cdot X-b=R$

where the matrix $A$ is defined as the physicochemical characteristics of the source water types, column $X$ is composed of mixing ratios $\left(x_{i}\right)$ among the source water masses, the

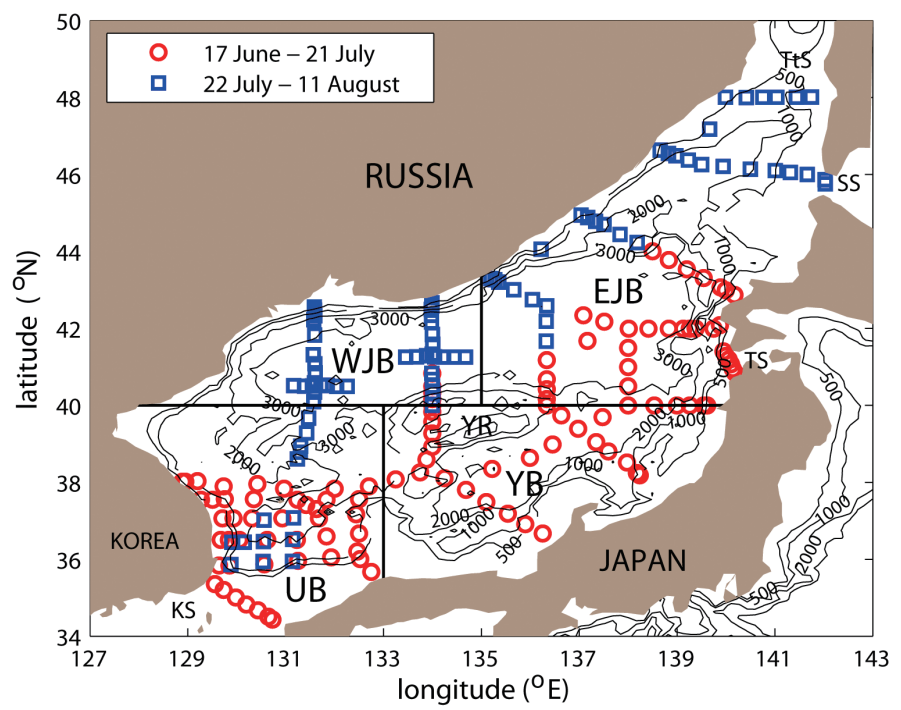

Fig. 1. Map showing the hydrographic stations of 1999 Summer Circulation Research of East Asian Marginal Seas II (CREAMS II) program and topography of the East/Japan Sea (EJS). The EJS is consisted of three basins; JB (Japan basin), YB (Yamato Basin), and UB (Ulleung Basin), one rise; YR (Yamato Rise), and four straits; KR (Korea Strait), TS (Tsugaru Strait), ST (Soya Strait), and TtS (Tatar Strait). The Japan Basin at $135^{\circ} \mathrm{E}$ was divided into the Western Japan Basin (WJB) and the Eastern Japan Basin (EJB) to facilitate analysis. 
amount of remineralized phosphate $\left(\Delta P_{\text {remi }}\right)$, the amount of denitrification $\left(\Delta N_{\text {deni }}\right)$, the amount of inorganic carbonate dissolution $\left(\Delta C_{\text {inorg }}\right)$, and the amount of inorganic silicate dissolution $\left(\Delta S i_{i n o r g}\right)$. The column $b$ is the observations, and column $R$ is the residuals of parameters. The last row that consists of ' 1 ' is to constrain the mass conservation $\left(\sum x_{i}=1\right)$. The ratios of $r_{C: S: N: P:-O_{2}}$ indicate the Redfield ratios, and $r_{D}$ is the amount of phosphate produced by denitrification and is given as 1/104 (Gruber and Sarmiento 1997). The eOMP analysis is based on an over-determined system, meaning that there are more equations than unknown variables, so the solutions $\left(x_{i}, \Delta P_{\text {remi }}, \Delta N_{\text {deni }}, \Delta C_{\text {inorg }}\right.$, and $\left.\Delta S i_{\text {inorg }}\right)$ are found by minimizing residuals with non-negativity (Tomczak and Large 1989). Here, the amount of denitrification $\left(\Delta N_{\text {deni }}\right)$ among biogeochemical changes is the primary focus in this study.

\subsection{Physicochemical Characteristics of Source Water Types}

The physicochemical characteristics of eight different water masses in the EJS were defined using geographical locations and water properties including temperature, salinity, and dissolved oxygen: (1) North Korea Surface Water (NKSW; surface water), (2) East Korean Coastal Water (EKCW; surface water), (3) Modified Tsushima Surface Water (MTSW; surface water), (4) Tatar Surface Cold Water (TSCW; surface water), (5) Tsushima Middle Water (TMW; intermediate water), (6) Liman Cold Water (LCW; intermediate water), (7) East Sea Intermediate Water (ESIW; intermediate and deep water), and (8) East Sea Proper Water (ESPW; deep water) (Kim and Lee 2004; Kim et al. 2010a). The source water types (1) - (4) are surface water, (5) - (7) are intermediate water, and (7) - (8) are deep water. Because only data collected deeper than $300 \mathrm{~m}$ is considered, only TMW, LCW, ESIW, and ESPW were used in the eOMP analysis (Table 1).

\subsection{Redfield Ratios and Weights Used for the eOMP Analysis}

The estimations of biogeochemical changes in the eOMP analysis are expressed as the Redfield ratios $\left(r_{C: S i N: P_{:}-O_{2}}\right)$. The traditional Redfield ratios, $r_{C: N: P:-O_{2}}=106: 16: 1: 138$, have been used widely (Redfield et al. 1963). These ratios are common in the open oceans. However, recent observations indicate that the Redfield ratios should be revised slightly. For example, the traditional Redfield ratios were reexamined through a non-linear approach in deep oceans $(>400 \mathrm{~m})$, and a revision of $r_{C: N: P:-O_{2}}=(117 \pm 14):(16 \pm 1): 1:(170 \pm 10)$ was suggested (Anderson and Sarmiento 1994). Subsequently, the mean organic matter composition of marine phytoplankton was reanalyzed and the Redfield ratios were revised to $r_{C: N: P:-O_{2}}=106: 16: 1:(150 \pm 10)$ (Anderson 1995). The EJS's
Redfield ratios fitted by linear regression analysis (> $300 \mathrm{~m})$ were estimated here as $r_{C: N: P:-O_{2}}=103: 12.4: 1: 118$. Four different cases were considered to check the sensitivity from using differentRedfieldratios:(case 1) $r_{C: N: P:-O_{2}}=106: 16: 1: 138$, (case 2) $r_{C: N: P:-O_{2}}=117: 16: 1: 170$, (case 3) $r_{C: N: P:-O_{2}}=106: 16: 1: 150$, and (case 4) $r_{C: N: P:-O_{2}}=103: 12.4: 1: 118$. Cases $1-4$ were based on the ratio of $r_{S: P}=28$ estimated in the EJS. Mean denitrification values used in this study were an average taken from cases 1 - 4 .

Since each parameter shows different accuracy and precision, the eOMP analysis assigns a weight value for each parameter. The weight equation is given as (Kim and Lee 2004; Kim and Min 2013; Kim et al. 2013):

$W_{j}=\frac{\sigma_{j}}{\text { accuracy }_{j}}$

where $\sigma_{j}$ is the standard deviation of parameter $j$ calculated from the physicochemical characteristics of the source water types, and accuracy ${ }_{j}$ is the measurement error of parameter $j$. The weight values used for the eOMP analysis are summarized in Table 1. Note that the weight of DIC was assigned with the same value as that of TALK, because the DIC was estimated from TALK and the total $\mathrm{pH}$.

\subsection{Residuals of Mass Conservation}

The last column consisting of ' 1 ' in Eq. (1) constrains the mass conservation $\left(\sum_{i=1}^{4} x_{i}=1\right)$. This constraint serves as a tracer to examine the eOMP analysis validation results (Tomczak and Large 1989; Hupe and Karstensen 2000). The residuals of mass conservation $\left(R_{M C}\right)$ are calculated as follows:

$R_{M C}(\%)=\left(\sum_{i=1}^{4} x_{i}-1\right) \times 100$

Overall the residuals (cases $1-4$ ) were defined within $\sim 3 \%$.

\section{RESULTS AND DISCUSSION}

\subsection{Potential Denitrification Locations Expected}

The eOMP analysis suggested that the eight locations $\left(\Delta N_{\text {deni }}>0\right)$, intersected collectively from cases $1-4$, were locations where bottom water denitrification may occur in EJS (Fig. 2). Six locations (1 - 6) were in the UB, and two stations $(7-8)$ were in the EJB. Overall the denitrification spatial distribution estimated from the eOMP analysis was similar to that from the nitrate profile analysis (Kim et al. 2012), and the estimated denitrification is higher in the EJB than in the UB. The mean $\Delta N_{d e n i}$ values of the eight locations, averaged from the cases $1-4$, ranged from about $51 \pm 1$ to $530 \pm 330 \mu \mathrm{mol} \mathrm{m}^{-3}$ at the bottom layer (Table 2). 
Table 1. The physicochemical characteristics of source water types and weights used for the eOMP analysis in the EJS.

\begin{tabular}{c|cccccccc}
\hline SWT & PT $\left({ }^{\circ} \mathbf{C}\right)$ & $\mathbf{S}(\mathbf{p s u})$ & $\mathbf{D O}\left(\boldsymbol{\mu m o l ~ \mathbf { ~ g } ^ { - 1 } )}\right.$ & $\mathbf{S i}\left(\boldsymbol{\mu m o l ~ k g}{ }^{-1}\right)$ & $\mathbf{N}\left(\boldsymbol{\mu m o l ~ \mathbf { ~ g } ^ { - 1 } )}\right.$ & $\mathbf{P}\left(\boldsymbol{\mu m o l ~ \mathbf { ~ g } ^ { - 1 } )}\right.$ & $\mathbf{T A L K}\left(\boldsymbol{\mu m o l ~ \mathbf { ~ g } ^ { - 1 } )}\right.$ & $\mathbf{D I C}(\boldsymbol{\mu m o l ~ k g - 1})$ \\
\hline TMW & 19.518 & 34.504 & 219.10 & 2.90 & 0.85 & 0.17 & 2281.6 & 2004.0 \\
LCW & 1.740 & 33.829 & 351.43 & 6.20 & 3.61 & 0.45 & 2262.6 & 2091.5 \\
ESIW & 1.429 & 34.042 & 318.53 & 16.80 & 11.44 & 0.91 & 2264.5 & 2142.6 \\
ESPW & 0.126 & 34.065 & 197.63 & 89.40 & 25.86 & 2.12 & 2284.6 & 2258.3 \\
Weight & 142 & 142 & 45 & 43 & 31 & 30 & 3 & 3 \\
\hline
\end{tabular}

Note: TMW: Tsushima Middle Water, LCW: Liman Cold Water, ESIW: East Sea Intermediate Water, ESPW: East Sea Proper Water.

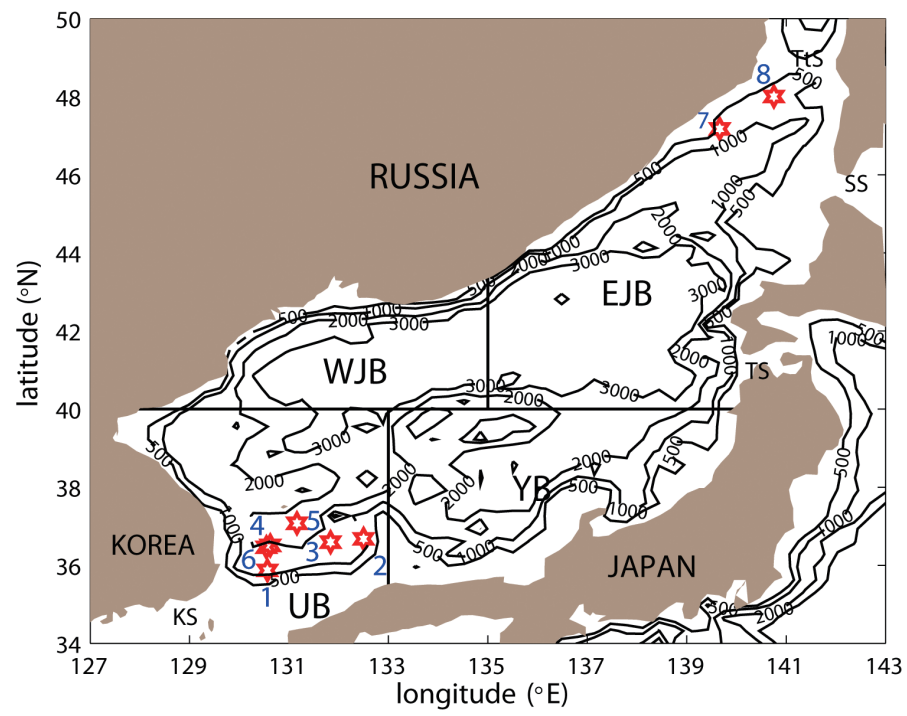

Fig. 2. The potential denitrification locations expected from the eOMP analysis. Those stations were intersected collectively from cases 1 - 4 (Table 2 ).

Table 2. Mean magnitude and rates of denitrification estimated at eight potential denitrification locations expected from the eOMP analysis.

\begin{tabular}{|c|c|c|c|c|c|c|c|c|}
\hline Basin & \multicolumn{6}{|c|}{ UB } & \multicolumn{2}{|c|}{ EJB } \\
\hline Location & 1 & 2 & 3 & 4 & 5 & 6 & 7 & 8 \\
\hline$\Delta a g e(y r)$ & 9.2 & 11.1 & 54.1 & 29.6 & 22.3 & 81.8 & 5.7 & 6.7 \\
\hline$\Delta H(m)$ & 64.9 & 93.5 & 297.1 & 117.0 & 82.0 & 427.6 & 69.7 & 99.7 \\
\hline$\Delta N_{d e n i}\left(\boldsymbol{\mu m o l ~ \mathbf { m } ^ { - 3 }}\right)$ & $210 \pm 20$ & $222 \pm 38$ & $333 \pm 1$ & $116 \pm 1$ & $51 \pm 1$ & $68 \pm 1$ & $186 \pm 214$ & $529 \pm 329$ \\
\hline 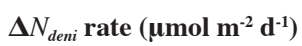 & $2.1 \pm 0.2$ & $3.0 \pm 0.5$ & $2.4 \pm 0.1$ & $0.6 \pm 0.1$ & $0.3 \pm 0.1$ & $0.4 \pm 0.1$ & $3.6 \pm 3.1$ & $10.7 \pm 6.7$ \\
\hline
\end{tabular}

Note: UB: Ulleung Basin (1 - 6), EJB: Eastern Japan Basin (7 - 8).

The rates of bottom water denitrification are estimated for the eight locations following the section 4.2.

\subsection{Denitrification Rates in the Bottom Layer}

The eOMP analysis provides the amount of denitrification with concentration. Information is needed to change concentration to rate unit, length $(\mathrm{m})$ and time $(\Delta \mathrm{T})$. As shown in
Fig. 3, denitrification is assumed to occur within the triangular area at the bottom $\left(=1 / 2 \times \Delta N_{\text {deni }} \times \Delta H\right)$. The time information $(\Delta \mathrm{T})$ between the upper and the lower boundary $(\Delta H)$ is estimated from the relative age concept (Poole and Tomczak 1999; Kim et al. 2012) defined by the apparent oxygen utilization $\left(\mathrm{AOU}=\left[\mathrm{O}_{2}\right]_{\text {saturation }}-\left[\mathrm{O}_{2}\right]_{\text {observed }} ; \mu \mathrm{mol} \mathrm{\textrm {kg } ^ { - 1 }}\right)$ divided by the oxygen utilization rate (OUR; $\mu$ mol $\mathrm{kg}^{-1} \mathrm{yr}^{-1}$ ). The OUR estimated for UB [OUR $(z)=6.592 e^{-0.0011-z}$, where $z$ is 
depth; Kim et al. 2010b] was used for the six locations (1 - 6), and the OUR estimated for $\operatorname{EJB}\left[\mathrm{OUR}(z)=10.680 e^{-0.00138-z}\right.$; Kim et al. 2010b] was used for the other two locations (7 - 8). This approach was described previously (Kim et al. 2012). The denitrification rate is estimated as:

$$
\Delta N_{\text {deni }}^{\text {rate }}=\frac{1}{2} \times \Delta N_{\text {deni }}\left(\frac{\mu m o l}{m^{3}}\right) \times \Delta H(m) / \Delta a g e(y r)
$$

The mean rates of bottom water denitrification estimated from the eOMP analysis in the UB ranged from $\sim 0.3 \pm 0.1$ to $3 \pm 1 \mu \mathrm{mol} \mathrm{N} \mathrm{m}{ }^{-2} \mathrm{~d}^{-1}$, and that in the EJB ranged from $\sim 4 \pm 3$ to $11 \pm 7 \mu \mathrm{mol} \mathrm{N} \mathrm{m}{ }^{-2} \mathrm{~d}^{-1}$ (Table 2 and Fig. 4). The rates estimated from the eOMP analysis are comparable to those estimated from nitrate profile analysis (UB: $4 \pm 1$ to $6 \pm 2 \mu \mathrm{mol} \mathrm{N} \mathrm{m}^{-2} \mathrm{~d}^{-1}$, EJB: $26 \pm 7 \mu \mathrm{mol} \mathrm{N} \mathrm{m}{ }^{-2} \mathrm{~d}^{-1}$; Kim et al. 2012).

\subsection{Comparisons with Other Marginal Seas}

Based on previous results (Kim et al. 2012) and this study, the EJS's denitrification rates range from 0.2 - 33 $(0.3 \pm 0.1$ to $26 \pm 7) \mu \mathrm{mol} \mathrm{N} \mathrm{m}{ }^{-2} \mathrm{~d}^{-1}$. The EJS's rates are comparable, but generally low, relative to those in other marginal seas. The denitrification rates estimated in the Adriatic Sea, the Arabian Sea, the Baltic Sea, the Black Sea, the North Sea, and the Okhotsk Sea ranged from $19-1151 \mu \mathrm{mol} \mathrm{N} \mathrm{m}^{-2} \mathrm{~d}^{-1}$ (Degobbis et al. 1986), 400 - $3780 \mu \mathrm{mol} \mathrm{N} \mathrm{m}{ }^{-2} \mathrm{~d}^{-1}$ (Schwartz et al. 2009), 150 - $881 \mu$ mol $\mathrm{N} \mathrm{m}^{-2} \mathrm{~d}^{-1}$ (Tuominen et al. 1998; Voss et al. 2005; Gustafsson and Stigebrandt 2007), $48-560 \mu \mathrm{molN} \mathrm{m}^{-2} \mathrm{~d}^{-1}$ (McCarthy et al. 2007), $1-150 \mu \mathrm{mol} \mathrm{N} \mathrm{m} \mathrm{m}^{-2} \mathrm{~d}^{-1}$ (Law and Owens 1990), and $356-1069 \mu \mathrm{mol} \mathrm{N} \mathrm{m}{ }^{-2} \mathrm{~d}^{-1}$ (Andreev and Pavlova 2010), respectively. Although the denitrification rates in other marginal seas had broad ranges, overall they were higher than the EJS rates.

\subsection{Implication for a Climate Feedback Loop in the EJS}

Although the mechanism driving denitrification in the EJS is not yet understood, we speculate that EJS denitrification are enhanced by the rapid responses of EJS to climate change - for examples, increase in sea surface temperature, slowdown of deep-water formation system, and in turn a decrease in oxygen content in the deep/bottom waters (Kim and Kim 1996; Gamo 1999; Chen et al. 1999; Gamo et al. 2001; Kim et al. 2001, 2004; Kang et al. 2003, 2004; Chae et al. 2005). If these changes occur continuously in the EJS, the oxygenated deep/bottom waters will be changed progressively to low oxygen waters, a condition favoring denitrification $\left(\mathrm{NO}_{3}{ }^{-} \rightarrow \mathrm{NO}_{2}{ }^{-} \rightarrow \mathrm{N}_{2} \mathrm{O} / \mathrm{N}_{2}\right)$. Nitrous oxide $\left(\mathrm{N}_{2} \mathrm{O}\right)$, a strong greenhouse gas (Solomon et al. 2007), is produced during the denitrification process. As a result, we expect that a positive feedback loop may be formed in the EJS in the future (Fig. 5), if climate change patterns continue or increase in the EJS environment.

\section{SUMMARY AND FUTURE STUDY}

The main purpose of this study was to estimate denitrification rates in the EJS using the eOMP analysis and compare the results with those estimated previously using nitrate profile analysis (Kim et al. 2012). The results indicate that the potential denitrification locations expected from the eOMP analysis were located in UB and EJB. Mean denitrification rates were estimated as $\sim 0.3-3$ and $\sim 4-11 \mu \mathrm{mol} \mathrm{N} \mathrm{m} \mathrm{m}^{-2} \mathrm{~d}^{-1}$ in the UB and the EJB, respectively. The rates are consistent with those estimated by the nitrate profile analysis.

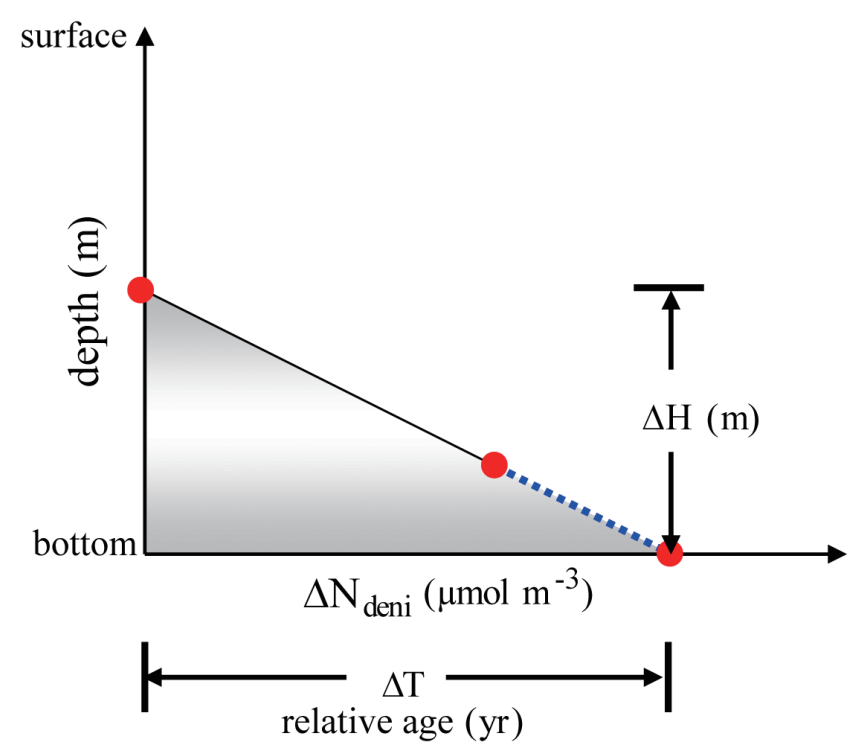

Fig. 3. An illustration to estimate denitrification rate. It is assumed that denitrification occurs within the triangular area $\left(=1 / 2 \times \Delta N_{\text {deni }} \times \Delta H\right)$. The time information $(\Delta \mathrm{T})$ between the upper and the lower boundary is estimated from the relative age concept. 


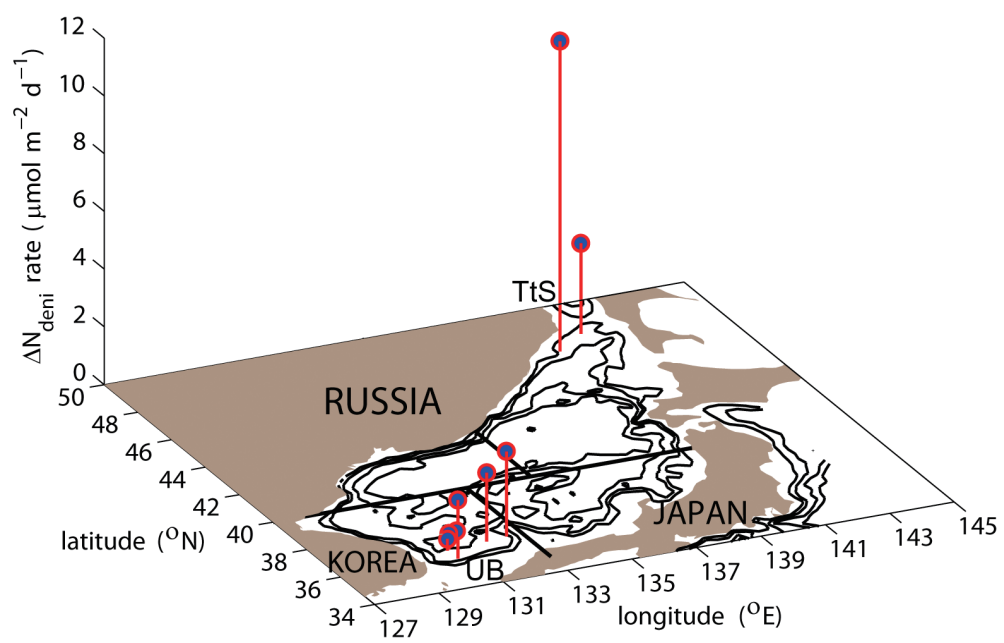

Fig. 4. Map showing the magnitude of mean denitrification rates $\left(\mu \mathrm{mol} \mathrm{N} \mathrm{m} \mathrm{m}^{-2} \mathrm{~d}^{-1}\right)$ estimated from the eOMP analysis.

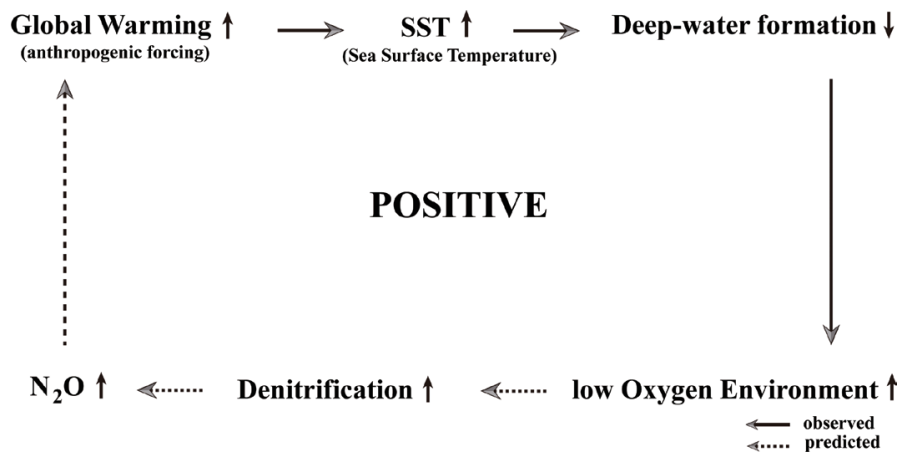

Fig. 5. An expected loop of climate feedback associated with denitrification in the EJS.

However, big questions remain about denitrification in the EJS, such as (1) "Where exactly do the denitrification signals originate (bottom water vs. sediment)?" and (2) "What mechanisms drive the denitrification process?". At present, direct evidence is not yet available to elucidate these questions. We suggest that a synthesized survey, including $\mathrm{O}_{2}$, nutrients $\left(\mathrm{NO}_{2}^{-}, \mathrm{NO}_{3}^{-}\right.$, and $\left.\mathrm{PO}_{4}{ }^{3-}\right)$, isotopes $\left(\delta^{15} \mathrm{~N}\right.$ and $\delta^{18} \mathrm{O}$ ), and molecular information, is needed to identify denitrifying bacteria at the denitrification locations predicted in the EJS.

Considering the rapid responses of EJS to climate change, denitrification may be enhanced in the near future. Therefore, a denitrification study will be an important key to understanding the EJS's nitrogen cycle, and indicating changes expected in EJS deep/bottom environments.

Acknowledgements I sincerely thank all of the people who contributed to the CREAMS II program. I thank D. H. Min (The University of Texas at Austin) and W. S. Gardner (The University of Texas at Austin) for their valuable comments. I thank the two Reviewers for their constructive comments and time.

\section{REFERENCES}

Anderson, L. A., 1995: On the hydrogen and oxygen content of marine phytoplankton. Deep-Sea Res. Part I-Oceanogr. Res. Pap., 42, 1675-1680, doi: 10.1016/09670637(95)00072-E. [Link]

Anderson, L. A. and J. L. Sarmiento, 1994: Redfield ratios of remineralization determined by nutrient data analysis. Global Biogeochem. Cycles, 8, 65-80, doi: 10.1029/93GB03318. [Link]

Andreev, A. and G. Pavlova, 2010: Okhotsk Sea. In: Liu, K. K., L. Atkinson, R. Quiñones, L. Talaue-McManus (Eds.), Carbon and Nutrient Fluxes in Continental Margins: A Global Synthesis, Global Change - The IGBP Series, Springer-Verlag Berlin Heidelberg, 394-405, doi: 10.1007/978-3-540-92735-8. [Link]

Brandes, J. A., A. H. Devol, and C. Deutsch, 2007: New developments in the marine nitrogen cycle. Chem. Rev., 107, 577-589, doi: 10.1021/cr050377t. [Link]

Chae, Y. K., Y. H. Seung, and S. K. Kang, 2005: Mode change of deep water formation deduced from slow variation of thermal structure: One-dimensional model 
study. Ocean Polar Res., 27, 115-123, doi: 10.4217/ OPR.2005.27.2.115. (in Korean) [Link]

Chen, C. T. A., A. S. Bychkov, S. L. Wang, and G. Y. Pavlova, 1999: An anoxic Sea of Japan by the year 2200? Mar. Chem., 67, 249-265, doi: 10.1016/S03044203(99)00074-2. [Link]

Degobbis, D., M. Gilmartin, and N. Revelante, 1986: An annotated nitrogen budget calculation for the northern Adriatic Sea. Mar. Chem., 20, 159-177, doi: 10.1016/0304-4203(86)90037-X. [Link]

Gamo, T., 1999: Global warming may have slowed down the deep conveyor belt of a marginal sea of the northwestern Pacific: Japan Sea. Geophys. Res. Lett., 26, 3137-3140, doi: 10.1029/1999GL002341. [Link]

Gamo, T., N. Momoshima, and S. Tolmachyov, 2001: Recent upward shift of the deep convection system in the Japan Sea, as inferred from the geochemical tracers tritium, oxygen, and nutrients. Geophys. Res. Lett., 28, 4143-4146, doi: 10.1029/2001GL013367. [Link]

Gruber, N. and J. L. Sarmiento, 1997: Global patterns of marine nitrogen fixation and denitrification. Global Biogeochem. Cycles, 11, 235-266. doi: 10.1029/97GB00077. [Link]

Gustafsson, B. G. and A. Stigebrandt, 2007: Dynamics of nutrients and oxygen/hydrogen sulfide in the Baltic Sea deep water. J. Geophys. Res., 112, G02023, doi: 10.1029/2006JG000304. [Link]

Hupe, A. and J. Karstensen, 2000: Redfield stoichiometry in Arabian Sea subsurface waters. Global Biogeochem. Cycles, 14, 357-372, doi: 10.1029/1999GB900077. [Link]

Jeong, J. H., D. S. Kim, T. H. Lee, and S. An, 2009: High remineralization and denitrification activity in the shelf sediments of Dok Island, East Sea. The Sea, 14, 80-89. (in Korean)

Kang, D. J., S. Park, Y. G. Kim, K. Kim, and K. R. Kim, 2003: A moving-boundary box model (MBBM) for oceans in change: An application to the East/Japan Sea. Geophys. Res. Lett., 30, doi: 10.1029/2002GL016486. [Link]

Kang, D. J., J. Y. Kim, T. Lee, and K. R. Kim, 2004: Will the East/Japan Sea become an anoxic sea in the next century? Mar. Chem., 91, 77-84, doi: 10.1016/j. marchem.2004.03.020. [Link]

Kim, I. N. and T. Lee, 2004: Summer hydrographic features of the East Sea analyzed by the Optimum Multiparameter method. Ocean Polar Res., 26, 581-594, doi: 10.4217/OPR.2004.26.4.581. (in Korean) [Link]

Kim, I. N. and D. H. Min, 2013: Temporal variation of summertime denitrification rates in the Texas-Louisiana inner shelf region in the Gulf of Mexico: A modeling approach using the extended OMP analysis. Cont. Shelf Res., 66, 49-57, doi: 10.1016/j.csr.2013.07.005. [Link]

Kim, I. N., D. H. Min, D. H. Kim, and T. Lee, 2010a: In- vestigation of the physicochemical features and mixing of East/Japan Sea Intermediate Water: An isopycnic analysis approach. J. Mar. Res., 68, 799-818, doi: 10.1357/002224010796673849. [Link]

Kim, I. N., D. H. Min, and T. Lee, 2010b: Estimates of basin-specific oxygen utilization rates (OURs) in the East Sea (Sea of Japan). The Sea, 15, 86-96. (in Korean)

Kim, I. N., D. H. Min, and T. Lee, 2012: Deep nitrate deficit observed in the highly oxygenated East/Japan Sea and its possible cause. Terr. Atmos. Ocean. Sci., 23, 671683, doi: 10.3319/TAO.2012.08.11.01(Oc). [Link]

Kim, I. N., D. H. Min, and A. M. Macdonald, 2013: Water column denitrification rates in the oxygen minimum layer of the Pacific Ocean along $32^{\circ} \mathrm{S}$. Global Biogeochem. Cycles, 27, 816-827, doi: 10.1002/gbc.20070. [Link]

Kim, K., K. R. Kim, D. H. Min, Y. Volkov, J. H. Yoon, and M. Takematsu, 2001: Warming and structural changes in the east (Japan) Sea: A clue to future changes in Global Oceans? Geophys. Res. Lett., 28, 3293-3296, doi: 10.1029/2001GL013078. [Link]

Kim, K., K. R. Kim, Y. G. Kim, Y. K. Cho, D. J. Kang, M. Takematsu, and Y. Volkov, 2004: Water masses and decadal variability in the East Sea (Sea of Japan). Prog. Oceanogr., 61, 157-174, doi: 10.1016/j. pocean.2004.06.003. [Link]

Kim, K. R. and K. Kim, 1996: What is happening in the East Sea (Japan Sea)?: Recent chemical observations during CREAMS 93-96. J. Kor. Soc. Oceanogr., 31, 164-172.

Law, C. S. and N. J. P. Owens, 1990: Denitrification and nitrous oxide in the North Sea. Neth. J. Sea Res., 25, 65-74, doi: 10.1016/0077-7579(90)90009-6. [Link]

Lee, T., I. N. Kim, D. J. Kang, and D. Kim, 2007: Implications of deep nitrite in the Ulleung Basin. The Sea, 12, 239-243. (in Korean)

McCarthy, J. J., A. Yilmaz, Y. Coban-Yildiz, and J. L. Nevins, 2007: Nitrogen cycling in the offshore waters of the Black Sea. Estuar. Coast. Shelf Sci., 74, 493-514, doi: 10.1016/j.ecss.2007.05.005. [Link]

Min, H. S. and C. H. Kim, 2006: Water mass formation variability in the intermediate layer of the East Sea. Ocean Sci.J., 41, 255-260, doi: 10.1007/BF03020629. [Link]

Poole, R. and M. Tomczak, 1999: Optimum multiparameter analysis of the water mass structure in the Atlantic Ocean thermocline. Deep-Sea Res. Part IOceanogr. Res. Pap., 46, 1895-1921, doi: 10.1016/ S0967-0637(99)00025-4. [Link]

Redfield, A. C., B. H. Ketchum, and F. A. Richards, 1963: The influence of organisms on the composition of seawater. In: Hill, M. N. (Ed.), The Sea, Vol. 2, Wiley Interscience, New York, 26-77.

Schwartz, M. C., C. Woulds, and G. L. Cowie, 2009: Sedimentary denitrification rates across the Arabian 
Sea oxygen minimum zone. Deep-Sea Res. Part IITop. Stud. Oceanogr., 56, 324-332, doi: 10.1016/j. dsr2.2008.05.028. [Link]

Solomon, S., D. Qin, M. Manning, Z. Chen, M. Marquis, K. B. Averyt, M. Tignor and H. L. Miller, 2007: Climate Change 2007: The Physical Science Basis, Contribution of Working Group I to the Fourth Assessment Report of the Intergovernmental Panel on Climate Change, Cambridge University Press, Cambridge, United Kingdom and New York, NY, USA, 996 pp.

Talley, L. D., P. Y. Tishchenko, G. Mitchell, D. J. Kang, D. H. Min, A. Nedashkovskiy, D. Masten, and P. Robbins, 2001: Nitrite in a deep oxygenated environment The Japan/East Sea and Ulleung Basin. CREAMS '01 February, 2001, Honolulu, HI. Available at http://sam. ucsd.edu/onr jes/talley/creams2001 talley/creams 01 ppt dir/.

Talley, L. D., P. Tishchenko, V. Luchin, A. Nedashkovskiy, S. Sagalaev, D. J. Kang, M. Warner, and D. H. Min, 2004: Atlas of Japan (East) Sea hydrographic properties in summer, 1999. Prog. Oceanogr., 61, 277-348, doi: 10.1016/j.pocean.2004.06.011. [Link]

Talley, L. D., D. H. Min, V. B. Lobanov, V. A. Luchin, V. I. Ponomarev, A. N. Salyuk, A. Y. Shcherbina, P. Y. Tishchenko, and I. Zhabin, 2006: Japan/East Sea water masses and their relation to the sea's circulation. Oceanography, 19, 32-49, doi: 10.5670/oceanog.2006.42. [Link]
Tishchenko, P. Y., L. D. Talley, V. B. Lobanov, A. P. Nedashkovskii, G. Y. Pavlova, and S. G. Sagalaev, 2007: The influence of geochemical processes in the nearbottom layer on the hydrochemical characteristics of the waters of the Sea of Japan. Oceanology, 47, 350359, doi: 10.1134/S0001437007030071. [Link]

Tomczak, M. and D. G. B. Large, 1989: Optimum Multiparameter analysis of mixing in the thermocline of the eastern Indian Ocean. J. Geophys. Res., 94, 1614116149, doi: 10.1029/JC094iC11p16141. [Link]

Tuominen, L., A. Heinänen, J. Kuparinen, and L. P. Nielsen, 1998: Spatial and temporal variability of denitrification in the sediments of the northern Baltic Proper. Mar. Ecol. Prog. Ser., 172, 13-24, doi: 10.3354/ meps 172013. [Link]

Van Heuven, S., D. Pierrot, E. Lewis, and D. W. R. Wallace, 2011: CO2SYS v 1.1: MATLAB program developed for $\mathrm{CO}_{2}$ system calculations. ORNL/CDIAC-105b, Carbon Dioxide Information Analysis Center, Oak Ridge National Laboratory, US Department of Energy, Oak Ridge, Tenessee.

Voss, M., K. C. Emeis, S. Hille, T. Neumann, and J. W. Dippner, 2005: Nitrogen cycle of the Baltic Sea from an isotopic perspective. Global Biogeochem. Cycles, 19, GB3001, doi: 10.1029/2004GB002338. [Link]

Yanagi, T., 2002: Water, salt, phosphorus and nitrogen budgets of the Japan Sea. J. Oceanogr., 58, 797-804, doi: 10.1023/A:1022815027968. [Link] 